\title{
Genetic resistance of Eucalyptus globulus to autumn gum moth defoliation and the role of cuticular waxes
}

\author{
T.H. Jones, B.M. Potts, R.E. Vaillancourt, and N.W. Davies
}

\begin{abstract}
This study investigated the association between resistance of Eucalyptus globulus Labill. to autumn gum moth (Mnesempala privata Guenée) defoliation and cuticular wax compounds. In a field trial consisting of clonally replicated $\mathrm{F}_{2}$ families of E. globulus, situated in Tasmania, Australia, significant genetic variation in resistance was detected in two of three $\mathrm{F}_{2}$ families. The broad-sense heritability for defoliation within families ranged from 0.24 to 0.33 . The 15 most resistant and the 15 most susceptible genotypes within each variable family were compared for their relative levels of 26 cuticular wax compounds. While no significant correlation between resistance and total wax yield estimates was found, significant differences were detected between resistant and susceptible classes in the relative quantities of several aliphatic phenylethyl and benzyl wax esters within both families. This association does not appear to be a response induced by defoliation. The broad-sense heritabilities of the variation in these compounds were high (0.82-0.94). Our findings suggest that these wax compounds are a mechanism of genetic resistance to autumn gum moth in E. globulus.
\end{abstract}

\begin{abstract}
Résumé : Le but de cette recherche consistait à étudier la relation entre la résistance d'Eucalyptus globulus Labill. à la défoliation par Mnesempala privata Guenée et la composition de la cire cuticulaire. Une variation génétique significative pour la résistance a été détectée chez deux des trois familles $F_{2}$ dans un essai au champ avec des clones de familles $\mathrm{F}_{2}$ de E. globulus en Tasmanie (Australie). L'héritabilité au sens large de la résistance à la défoliation chez les familles variait de 0,24 à 0,33 . Les 15 génotypes les plus résistants et les 15 plus susceptibles dans chaque famille ont été comparés pour le niveau de 26 composés présents dans la cire cuticulaire. Bien qu'aucune corrélation significative n'ait été observée entre la résistance et les rendements totaux en cire, des différences significatives entre les clones résistants et susceptibles ont été détectées dans la quantité relative de plusieurs esters aliphatiques de phényléthyle et de benzyle présents dans la cire chez les deux familles. Cette association ne semble pas être une réponse induite par la défoliation. L'héritabilité au sens large de la variation dans ces composés est élevée $(0,82-0,94)$. Nos résultats indiquent que la présence de ces composés dans la cire constitue un mécanisme de résistance génétique à $M$. privata chez E. globulus.
\end{abstract}

[Traduit par la Rédaction]

\section{Introduction}

The larvae of the autumn gum moth (AGM) Mnesempala privata Guenée (Lepidoptera: Geometridae) can cause severe defoliation of Eucalyptus globulus Labill. juvenile foliage (Neumann and Collett 1997). It is a pest during the first 4 years of plantation establishment as E. globulus is markedly heteroblastic, changing to adult foliage at between 2 and 4 years of age (Jordan et al. 1999). The nocturnally active moths lay eggs in batches of around 75 on both surfaces of juvenile leaves (Elliot and Bashford 1978). The

Received 26 April 2001. Accepted 14 June 2002. Published on the NRC Research Press Web site at http://cjfr.nrc.ca on 12 October 2002.

T.H. Jones, ${ }^{1}$ B.M. Potts, and R.E. Vaillancourt. Cooperative Centre for Sustainable Production Forestry, School of Plant Science, University of Tasmania, G.P.O. Box 252-55, Hobart, 7001, Tasmania, Australia.

N.W. Davies. Central Science Laboratory, University of Tasmania, G.P.O. Box 252-74, Hobart, 7001, Tasmania, Australia.

${ }^{1}$ Corresponding author (e-mail: tjones@utas.edu.au). eggs normally hatch in early to mid-autumn (McQuillan 1985) and the larvae feed gregariously on leaf epidermis and mesophyll tissue during the first and second instar stages, while the third to final fifth instar larvae disperse and feed solitarily. The late instars are capable of completely devouring leaf tissue, leaving only the midrib (Wills and Burbidge 1995). The larval stage lasts between 1 and 2 months depending on temperature, although defoliation may be observed in the field for a much longer period as oviposition may occur over several months (Lukacs 1998).

Twenty-seven eucalypt species have been reported as prone to damage by autumn gum moth larvae (Neumann and Collett 1997), including Eucalyptus nitens Dean \& Maid. and E. globulus (Elliot and Bashford 1978), which are the major commercial eucalypt species in temperate regions of the world (Tibbits et al. 1997). Autumn gum moth is a serious plantation pest in southern Australia (Fremlin 1998; Neumann and Collett 1997), including Tasmania (Elliot and deLittle 1984). Individual trees or entire plantations in the juvenile phase may be totally defoliated leading to a reduction in productivity and high mortality (Neumann and Collett 1997). Genetic variation in susceptibility of E. globulus to AGM has been reported (Floyd et al. 1994), 
and resistant genotypes could be introduced as part of an integrated strategy to manage the autumn gum moth problem and reduce pesticide use (Floyd and Farrow 1994). However, one problem in breeding for resistance to pests and diseases is that without a bioassay, expression of resistance variation is dependent on pest outbreaks that are unpredictable and uncontrolled. Marker-assisted selection offers an alternative (e.g., Wu et al. 2000; Watanabe et al. 2000) but suffers from large costs, unpredictable linkage phase, and recombination (Strauss et al. 1992). The candidate gene approach allows a direct method of selecting resistant genotypes (Stotz et al. 1999), but development time may be long and the assay expensive. Identification of the mechanisms of resistance allows direct selection of resistant genotypes.

A large array of foliar characteristics have been reported to directly affect eucalypt susceptibility to insect attack including foliar oils (e.g., Edwards et al. 1990; Stone and Bacon 1994), waxes (Edwards 1982), phenolics (e.g., Landsberg 1990), nitrogen content (Ohmart and Edwards 1991), and leaf toughness (Edwards and Wanjura 1990). However, their role in determining the resistance of E. globulus to autumn gum moth defoliation is currently unknown. Our long-term aim is to identify the mechanism(s) of genetic resistance to autumn gum moth defoliation in E. globulus, which will allow selection of genotypes better suited for deployment in high-risk areas. This paper investigates the role of cuticular waxes in the genetic resistance of juvenile E. globulus trees to defoliation by the autumn gum moth using three large, clonally replicated, inter- and intraprovenance $\mathrm{F}_{2}$ families.

\section{Methods}

\section{Field trial}

Genetic variation in susceptibility to autumn gum moth (AGM) defoliation was studied in a field trial in northwestern Tasmania $\left(40^{\circ} 52^{\prime} \mathrm{S}, 144^{\circ} 50^{\prime} \mathrm{E}\right)$ on Gunns Ltd. land. The trial was established in May 1998 and included three $F_{2}$ families with grandparents originating from the King Island (KI) and Taranna $(\mathrm{T})$ provenances (family 1 , $(\mathrm{T} 7 \times \mathrm{KI} 7) \times$ $(\mathrm{T} 144 \times \mathrm{KI} 5)$; family 2 , $(\mathrm{T} 7 \times \mathrm{KI} 157) \times(\mathrm{KI} 5 \times \mathrm{KI} 157)$; family $3,(\mathrm{KI} 2 \times \mathrm{KI} 161) \times(\mathrm{KI} 5 \times \mathrm{KI} 157))$. The three families contained 240, 238, and 178 genotypes, respectively. Of these, 160, 160, and 100 genotypes were replicated clonally (as ramet and ortet), resulting in two trees per genotype. The remaining genotypes were represented by one tree. The trial contained two replicates, each with 20 incomplete blocks of 30 or 36 individuals. Each incomplete block contained 8 individuals from both family 1 and family 2, 5 individuals from family 3 and 5 or 11 unreplicated ortets randomly selected from the three families. Clonal replication of the $F_{2}$ allowed genetic and environmental (including patchiness in pest distributions) effects to be separated and the ranking of individual genotypes for their susceptibility to AGM defoliation (e.g., James and Newcombe 2000).

\section{Assessment of susceptibility}

A number of AGM larvae and unhatched eggs were observed in the trial at the beginning of a severe outbreak in early autumn, 1999. By late autumn (May), the field trial had been variably defoliated and was assessed over 4 days in
June 1999. At this stage, plants were 50-260 cm tall and still retained their juvenile foliage. Defoliation caused by AGM was scored in five different ways. Two scores were based on visual assessment of the whole tree (TDAM and MIN) and three scores from sampling a single branch chosen at random on the eastern side of the tree at two-thirds of the tree height (LNO, AREA, LARVAE): (i) TDAM, a visual estimate of the total percentage of foliage damaged by both mining of the first and second instar larvae and total leaf tissue consumption by the third to fifth instar larvae (estimates were made in increments of $1 \%$ up to $20 \%$, then increments of $5 \%$ up to $30 \%$, then increments of $10 \%$ above this); (ii) MIN, the percentage of foliage that had been mined, showing the characteristic yellow, dead skeleton remaining; (iii) LNO, the number of leaves damaged by AGM in the first 10 leaves from the terminal bud on the single branch; (iv) AREA, an estimate of the total percentage area damaged on those ten leaves; and ( $v$ ) LARVAE, the presence or absence of individual larvae or evidence of their presence (e.g., fused leaves together to form a shelter) on the chosen branch.

All field scores (except LARVAE) were log transformed to optimize normality. The intercorrelations among field scores were calculated using Pearsons correlations with the PROC CORR procedure of SAS version 6.12. The log of the percentage total damage (L-TDAM) was selected for all subsequent analyses.

\section{Genetic and environmental factors affecting susceptibility}

A mixed model incorporating the effects of replicate (fixed), incomplete block within replicate (random), family (fixed), genotype within family (random), level of fungal damage (covariate), weed density (covariate), tree height (covariate), and random error was fitted in the PROC MIXED procedure of SAS to initially investigate how variation in severity of defoliation was partitioned. All individuals and genotypes were included. $F_{2}$ family least-squares means were calculated for the severity of damage and compared in a pairwise manner after the Tukey-Kramer adjustment (Sokal and Rohlf 1981). Weed density, tree height, and intensity of infection by the leaf fungus Mycosphaerella sp. were quantified in April 1999, just prior to the main AGM defoliation. A five-point scoring system was used to assess weed density in a radius of $1 \mathrm{~m}$ from the tree, taking into account weed height and percentage cover ((1) no weeds; (5) maximum cover, overtopping tree). The area of leaf damaged by the leaf spot fungi Mycosphaerella sp. was also assessed using a five-point scoring system ((1) 0-3\% leaf area infected; (5) 18-25\% leaf area infected; A. Milgate, unpublished data).

Having identified a significant effect of genotype within family, the three families were analyzed separately with a similar model but excluding the fixed family term. Only genotypes with clonal replication were included in these analyses. The broad-sense heritability $\left(h^{2}\right)$ of susceptibility to AGM was estimated for each family by calculating the clonal repeatability (Falconer 1990) as

[1] $h^{2}=\frac{\sigma_{\mathrm{g}}^{2}}{\sigma_{\mathrm{p}}^{2}}$ 
where $\sigma_{\mathrm{g}}^{2}$ is the component of variation between genotypes and $\sigma_{\mathrm{p}}^{2}$ is the total phenotypic component of variation calculated as the sum of the variation between genotypes $\left(\sigma_{\mathrm{g}}^{2}\right)$ and the variation between trees of the same genotype once replicate and incomplete block effects were removed (the error term in the model). Best linear unbiased predictions (BLUPS) of the genotype susceptibility within these families were then calculated, providing a ranking of genotypes from most susceptible (most defoliated) to most resistant (least defoliated). This model was also fitted with the PROC MIXED procedure of SAS.

\section{Foliage sampling}

A single clone from each of the 15 most resistant and 15 most susceptible genotypes in each of families 1 and 3 was chosen to be screened for cuticular waxes. Juvenile foliage from these individuals was sampled twice, firstly in September 1999, just prior to the main spring flush and secondly in February 2000, after aerial spraying of the trial with synthetic pyrethrum. This spraying was effective and resulted in undamaged, new foliage being available. In the first sampling, the healthiest foliage available was collected from throughout the canopy. Emerging spring growth occurred on about $30 \%$ of the trees but only the previous seasons' foliage, corresponding to the season of defoliation, was sampled. Five to 10 shoot tips were collected from the trees, cut three to five nodes back from the terminal bud complex, excluding the new seasons growth. Following collection, foliage was stored at $4{ }^{\circ} \mathrm{C}$ until analysed. In the second sampling, the same trees were resampled as previously described, except abundant undamaged foliage allowed sampling from a standard position (i.e., the west side of the trees at ca. $1.5 \mathrm{~m}$ height).

To test for potential induced effects of AGM defoliation on cuticular wax compounds, two additional experiments were carried out. During the 1999 sampling, both damaged and undamaged foliage from 20 minimally defoliated trees was collected and analysed separately to investigate the possibility of damage induced changes within a tree. During the 2000 sampling, clonal pairs from 15 genotypes were also sampled, selected on the basis that the two trees within the pair had very different levels of AGM defoliation in the previous year. The comparison of different trees of the same genotype that had suffered both high and low levels of defoliation provided a test of induced chemical responses at the whole tree level.

\section{Foliar chemistry}

Hexane soluble cuticular waxes were extracted from foliage 4-6 days after collection. The extraction protocol followed Li et al. (1997) with modifications for small foliage samples as detailed. Two grams (fresh mass) of least damaged foliage from each sample was weighed and cut into 1.0 - to $1.5-\mathrm{cm}^{2}$ square pieces (no difference has been detected in chemical composition between chopped and unchopped foliage in this situation, Li et al. 1997), excluding dry or dead leaf material. The extraction solvent was highperformance liquid chromatography grade hexane with $0.01 \% n$-tetradecane added as an internal standard. Foliage was placed in a glass flask with $10.0 \mathrm{~mL}$ of the extraction solvent, shaken for $1 \mathrm{~min}$ at room temperature, left for
50 min, during which time it was shaken twice for $1 \mathrm{~min}$. The extract was then poured into a glass vial, which was sealed with a foil-lined lid until analysis.

The wax extracts were analysed by combined gas chromatography - mass spectrometry (GC-MS) using a HewlettPackard 5890 gas chromatograph coupled to a 5970B series mass selective detector via an open split interface. Helium was used as the carrier gas. The waxes were separated with a $25 \mathrm{~m} \times 0.32 \mathrm{~mm}$ HP-1 (internal diameter) column, with a $0.17-\mu \mathrm{m}$ film thickness. One microlitre splitless injections of the samples were made with an injection port temperature of $300^{\circ} \mathrm{C}$. Initial column temperature was $60^{\circ} \mathrm{C}$ for $1 \mathrm{~min}$, raised to $200^{\circ} \mathrm{C}$ at $30^{\circ} \mathrm{C} / \mathrm{min}$, and then to $300^{\circ} \mathrm{C}$ at $10^{\circ} \mathrm{C} / \mathrm{min}$ and held for $8 \mathrm{~min}$. Flow rate was $4 \mathrm{~mL} / \mathrm{min}$. Mass spectra were collected at $1.9 \mathrm{scans} / \mathrm{s}$ scanning from $\mathrm{m} / \mathrm{z} 40$ to 550 .

Interpretation of mass spectra was based on a combination of an existing commercial database (National Institute of Standards and Technology) and specialized "in-house" libraries, with chain lengths of the various wax esters determined from molecular weight data and retention times. Relative abundance of compounds was calculated by measuring the area for the peak on a mass chromatogram of a diagnostic ion for the compound of interest. The use of diagnostic ions enabled measurement of areas independent of any partially unresolved components. Abundance was expressed as the ratio of the diagnostic ion current relative to the total ion current of the internal standard. The log of this ratio was used for statistical analysis as recommended by Birks and Kanowski (1993). An estimate of the total wax yield was obtained from this data by calculating the total ion current for the complete profile and expressing it as a ratio of the internal standard. For each compound, the PROC GLM procedure of SAS was used to test the fixed effects of family, susceptibility class, and their interaction. The significance of the difference between resistant and susceptible classes in the levels of each cuticular wax compound was also tested with a one-way ANOVA separately within each family. To account for multiple tests being done for the wax compounds, the conservative Bonferroni adjustment (Snedecor and Cochrane 1980) was applied. This adjustment was not necessary when testing the repeatability of specific compounds in the 2000 sample. To test for induced effects, the relative abundance of wax compounds from $(i)$ damaged and undamaged foliage from the same tree (sampled in 1999) and (ii) damaged and undamaged clones of the same genotype (sampled in 2000), in both families, was compared with a paired $t$ test. In addition, a one-way model fitting genotype as a random effect was used to test the differences between genotypes in the later sample using the MIXED procedure of SAS. The variance components estimated from this procedure were used to calculate the broad-sense heritability of wax compound abundance as in eq. 1 .

\section{Results}

\section{Field damage and detection of genetic variation}

The scoring of field damage in 1999 was made near the end of the AGM feeding season and its mean damage was $8 \%$ and ranged from 0 to $70 \%$ defoliation (TDAM). The only other dominant cause of foliar damage at the time of scoring was Mycosphaerella sp., and this damage, in the 
form of necrotic lesions on the leaf, was clearly differentiated from that caused by AGM. The five AGM defoliation scoring methods were highly correlated ( $r=0.59-0.90$; Table 1). The log transformed measure of total percentage defoliation (L-TDAM), used in subsequent analyses, had residuals that best fitted the normal distribution $(P=0.99)$ and was the easiest to assess in the field.

The analysis of variation in AGM defoliation over the three $F_{2}$ families (Table 2) suggested little spatial variation in defoliation across the field trial as replicate and incomplete block within replicate effects were insignificant. However, the level of defoliation was significantly $(P<0.001)$ affected by tree height and weed density. Defoliation was higher on taller trees with fewer surrounding weeds. While tree height itself was negatively correlated with weed density ( $r=-0.2 ; P<0.001)$, the high significance of both covariates in the mixed model suggests that their effects were operating independently. The amount of Mycosphaerella sp. fungal damage present prior to AGM defoliation had a marginally significant effect $(P<0.05)$ on the level of AGM defoliation. In addition to these factors, there were significant genetic differences between families $(P<$ $0.001)$ and genotypes within families $(P<0.001)$ (Table 2$)$. The significant family effect was due to the mean percentage of leaf area lost through AGM feeding being significantly $(P<0.001)$ less in family $1(6.1 \pm 0.4 \%)$ than either family $2(9.0 \pm 0.3 \%)$ or $3(10.4 \pm 0.6 \%)$. Individual family analyses indicated that significant genetic variation between genotypes was present in family $1(Z=2.4 ; P<0.05)$ and family $3(Z=2.8 ; P<0.01)$. Family 2 did not exhibit significant variation between genotypes $(Z=0.2 ; P>0.05)$. Therefore, resistant (least defoliated) and susceptible (most defoliated) genotypes were only selected from families 1 and 3 for comparison of chemical compounds. Resistant classes from families 1 and 3 exhibited mean defoliation scores of $1.8 \pm 0.4 \%$ and $2.9 \pm 0.5 \%$, respectively, while susceptible classes exhibited mean defoliation scores of $18.9 \pm 1.9 \%$ and $26.4 \pm 3.9 \%$, respectively.

\section{Association of resistance with cuticular wax compounds}

Within the six major classes of wax compounds investigated, totals of 18 and 24 individual wax compounds were analysed in the 1999 and 2000 analyses, respectively (Table 3). $\beta$-Diketones were dominant; however, eucalyptins, hexadecanal, and heptadecan-2-one were also abundant. Analysis of variance indicated clear differences in the levels of various wax compounds both between families and susceptibility class in the 1999 and 2000 samples (Table 3). In the 1999 sampling, total wax yield relative to the internal standard was significantly $(P<0.01)$ greater in family 3 than family 1 ; however, there was no significant $(P>0.05)$ variation in total wax yield between damage classes within families. In the 2000 sample, there was no significant variation in total wax yield (relative to the internal standard) between families. The compounds desmethyl eucalyptin (Table 3, compound 22) and eucalyptin (compound 23) could not be separated in the 2000 analysis and were combined as "eucalyptins" (compound 24). No significant variation between the two families or between susceptibility classes within families was detected in the strongly dominating $\mathrm{C}_{33}$
Table 1. Pearson's correlation coefficients between the five scoring techniques used to assess autumn gum moth damage $(0$, uncorrelated; 1 , perfectly correlated).

\begin{tabular}{lllll}
\hline & L-TDAM & L-MIN & L-LAREA & L-LNO \\
\hline L-MIN & 0.82 & - & - & - \\
L-LAREA & 0.76 & 0.66 & - & - \\
L-LNO & 0.73 & 0.68 & 0.90 & - \\
LARVAE & 0.62 & 0.59 & 0.75 & 0.81 \\
\hline
\end{tabular}

Note: All correlations were significant at the 0.001 level. Complete tree damage estimates: L-TDAM, $\log$ (total damage); L-MIN, $\log$ (leaf mining). Randomly selected branch damage estimates: L-LAREA, $\log$ (leaf area loss); L-LNO, $\log$ (number of leaves damaged); LARVAE, presenceabsence of larvae or larval shelter.

Table 2. The significance of genetic, biotic, and environmental effects within the field trial on the severity of defoliation caused by autumn gum moth (L-TDAM).

\begin{tabular}{lrrr}
\hline & df & $F$ or $Z$ & \multicolumn{1}{l}{$P$} \\
\hline Height & 1 & 20.83 & $<0.001$ \\
Weed competition & 1 & 65.04 & $<0.001$ \\
Mycosphaerella & 1 & 5.30 & 0.022 \\
Replicate & 1 & 1.93 & 0.166 \\
Incomplete block & 37 & 1.32 & 0.093 \\
Family & 2 & 24.05 & $<0.001$ \\
Genotype within family & 557 & 3.49 & $<0.001$ \\
Random error & 272 & - & - \\
\hline
\end{tabular}

Note: The analysis was carried out over all trees of families 1,2 , and 3 including clonally replicated and unreplicated individual genotypes.

$\beta$-diketone, $n$-tritriacontane-16,18-dione (Table 3, compound 19). In both the 1999 and the 2000 samples, significantly higher levels of a number of wax compounds including benzyl esters (Table 3, compounds 3, 7, and 8) and phenylethyl esters (Table 3, compounds 11, 16, 17) were found in the more resistant family 1 than family 3 (Table 3 ).

The key finding of this study is the discovery of a group of aliphatic benzyl and phenylethyl alkanoates with carbon chain lengths of 23 to 26, present in significantly higher quantities in the foliage of resistant compared with susceptible genotypes (Fig. 1, Table 3, compounds 5-7 and 13-16). The total abundance of this group of esters was significantly higher in the resistant class in both families and in both years and was also found in higher levels in the more resistant family 1 (Table 3, Fig. 1). While individual compounds within this group were not always significant in both families in both years, the trends were consistent (Fig. 2). In particular, the relative quantity of the benzyl alkanoate, benzyl n-tetracosanoate (compound 5) was significantly higher in the resistant classes in both years, and this compound also occurred in higher levels in the more resistant family 1 . When individual benzyl and phenylethyl alkanoates were expressed as a ratio of the dominant compound $n$ tritriacontane-16,18-dione instead of the internal standard, very similar results (data not shown) were obtained.

The two additional experiments suggested that these differences in wax ester content were not an induced response to damage. Firstly, in the 1999 sampling, there were no significant differences in the quantities of any of these wax 
Table 3. Probability levels for the differences in wax compounds among families (from the overall mixed model) and the comparison of 15 resistant and 15 susceptible genotypes (susceptibility class) within each variable family for the 1999 and 2000 foliage samples.

\begin{tabular}{|c|c|c|c|c|c|c|c|c|c|}
\hline \multirow[b]{2}{*}{ No. } & \multirow[b]{2}{*}{ Wax compound } & \multicolumn{2}{|c|}{ Among families } & \multicolumn{2}{|c|}{$\begin{array}{l}\text { Susceptibility } \\
\text { classes of family } 1\end{array}$} & \multicolumn{2}{|c|}{$\begin{array}{l}\text { Susceptibility } \\
\text { classes of family } 3\end{array}$} & \multicolumn{2}{|c|}{ Genotype } \\
\hline & & 1999 & 2000 & 1999 & 2000 & 1999 & 2000 & $\overline{h^{2}}$ & $P$ \\
\hline 1 & Benzyl $n$-eicosanoate $\left(\mathrm{C}_{20}\right)^{b}$ & $0.002 *$ & 0.147 & 0.116 & $0.001 *$ & 0.357 & 0.678 & 0.71 & 0.031 \\
\hline 2 & Benzyl $n$-heneicosanoate $\left(\mathrm{C}_{21}\right)$ & na & 0.172 & na & 0.054 & na & 0.973 & 0.27 & 0.320 \\
\hline 3 & Benzyl $n$-docosanoate $\left(\mathrm{C}_{22}\right)$ & $<0.001 *$ & $0.001 *$ & 0.024 & 0.976 & 0.531 & 0.355 & 0.27 & 0.320 \\
\hline 5 & Benzyl $n$-tetracosanoate $\left(\mathrm{C}_{24}\right)$ & 0.012 & 0.004 & $<0.001^{*}$ & $<0.001 *$ & $0.001 *$ & 0.005 & 0.82 & 0.018 \\
\hline 6 & Benzyl $n$-pentacosanoate $\left(\mathrm{C}_{25}\right)$ & na & 0.098 & na & $<0.001 *$ & na & 0.094 & 0.86 & 0.015 \\
\hline 7 & Benzyl $n$-hexacosanoate $\left(\mathrm{C}_{26}\right)$ & 0.340 & $<0.001^{*}$ & $0.001 *$ & $<0.001 *$ & 0.769 & 0.078 & 0.89 & 0.013 \\
\hline 8 & Benzyl $n$-octacosanoate $\left(\mathrm{C}_{28}\right)$ & na & $<0.001 *$ & na & 0.019 & na & 0.504 & 0.56 & 0.067 \\
\hline 9 & Benzyl $n$-triacontanoate $\left(\mathrm{C}_{30}\right)$ & na & 0.184 & na & 0.009 & na & 0.272 & 0.71 & 0.030 \\
\hline 13 & Phenylethyl $n$-tricosanoate $\left(\mathrm{C}_{23}\right)$ & na & 0.721 & na & $0.002 *$ & na & 0.018 & 0.93 & 0.011 \\
\hline 14 & Phenylethyl $n$-tetracosanoate $\left(\mathrm{C}_{24}\right)$ & 0.772 & 0.934 & $0.001 *$ & 0.007 & 0.453 & 0.016 & 0.94 & 0.011 \\
\hline 15 & Phenylethyl $n$-pentacosanoate $\left(\mathrm{C}_{25}\right)$ & 0.737 & 0.035 & $<0.001 *$ & $<0.001^{*}$ & 0.065 & 0.242 & 0.82 & 0.018 \\
\hline 16 & Phenylethyl $n$-hexacosanoate $\left(\mathrm{C}_{26}\right)$ & $0.002 *$ & $0.001 *$ & $<0.001 *$ & 0.387 & 0.010 & 0.015 & 0.86 & 0.015 \\
\hline \multirow[t]{2}{*}{17} & Phenylethyl $n$-octacosanoate $\left(\mathrm{C}_{28}\right)$ & 0.017 & $0.001 *$ & 0.100 & 0.045 & 0.381 & 0.933 & 0.75 & 0.025 \\
\hline & Total significant esters $\left(\mathrm{C}_{23}-\mathrm{C}_{26}\right)$ & 0.047 & $<0.001$ & $<0.001$ & $<0.001$ & 0.018 & 0.006 & 0.93 & 0.011 \\
\hline \multicolumn{10}{|c|}{ Aliphatic $\beta$-diketones $(m / z, 100)$} \\
\hline 18 & $n$-Hentriacontane-14,16-dione $\left(\mathrm{C}_{31}\right)$ & $<0.001 *$ & 0.305 & 0.022 & 0.005 & 0.367 & 0.458 & 0.56 & 0.067 \\
\hline 19 & $n$-Tritriacontane-16,18-dione $\left(\mathrm{C}_{33}\right)$ & 0.122 & 0.166 & 0.130 & 0.917 & 0.320 & 0.903 & 0.55 & 0.069 \\
\hline 20 & $n$-Tetratriacontane-16,18-dione $\left(\mathrm{C}_{34}\right)$ & $<0.001 *$ & na & 0.344 & na & 0.252 & na & na & na \\
\hline 26 & Heptadecan-2-one & 0.532 & 0.306 & 0.112 & 0.064 & 0.171 & 0.284 & 0.73 & 0.030 \\
\hline \multicolumn{10}{|c|}{ Aldehydes $(m / z, 82)$} \\
\hline 27 & Hexadecanal & 0.255 & 0.464 & 0.087 & 0.065 & 0.350 & 0.354 & 0.60 & 0.054 \\
\hline & Total wax yield & 0.002 & 0.411 & 0.375 & 0.054 & 0.382 & 0.738 & 0.42 & 0.149 \\
\hline
\end{tabular}

Note: The probability of the difference between 15 genotypes for which replicate clones were sampled $(P)$ and the estimates of broad-sense heritability $\left(h^{2}\right)$ of the variation in wax compounds are also shown. The eucalyptins (compound 24) assayed in 2000 included desmethyl eucalyptin (compound 22) and eucalyptin (compound 23). Total wax yield was estimated using the total ion current. na, not applicable. Asterisks indicate that compounds were significant after Bonferroni's adjustment for multiple comparisons.

${ }^{a}$ Diagnostic ions used in combination with retention times to identify each group of compounds are shown in parentheses.

${ }^{b}$ Carbon chain lengths of the aliphatic esters and $\beta$-diketones are indicated $\left(C_{n}\right)$.

compounds when damaged and undamaged foliage taken from the same tree were compared. Secondly, in the 2000 sampling, no significant differences were detected between trees that had been severely defoliated the previous year and those of the same genotype that were relatively undamaged. However, the quantities of all of the key C23-C26 esters (compounds 5-7 and 13-16) differed significantly $(P<$ 0.05 ) between the 15 genotypes for which replicate trees were sampled (Table 3). The limited data suggests that like susceptibility to defoliation, variation in these esters is under strong genetic control, with broad-sense heritabilities ranging from 0.82 to 0.94 for individual compounds. The broadsense heritability for the total relative quantity of significant benzyl and phenylethyl esters is 0.93 (Table 3).

\section{Discussion}

While genetic variation in resistance to AGM occurs between provenances of E. globulus (Farrow et al. 1994), the present study indicates that genetic variation in resistance 
Fig. 1. Mean relative abundance of the benzyl and phenylethyl alkanoate group that exhibited significant variation between resistant and susceptible groups. Means from both families are shown from the 1999 and 2000 analysis. Quantities (abundance) are expressed as the sum of the diagnostic ion concentration (GC-MS) of each compound within the group relative to internal standard total ion concentration.

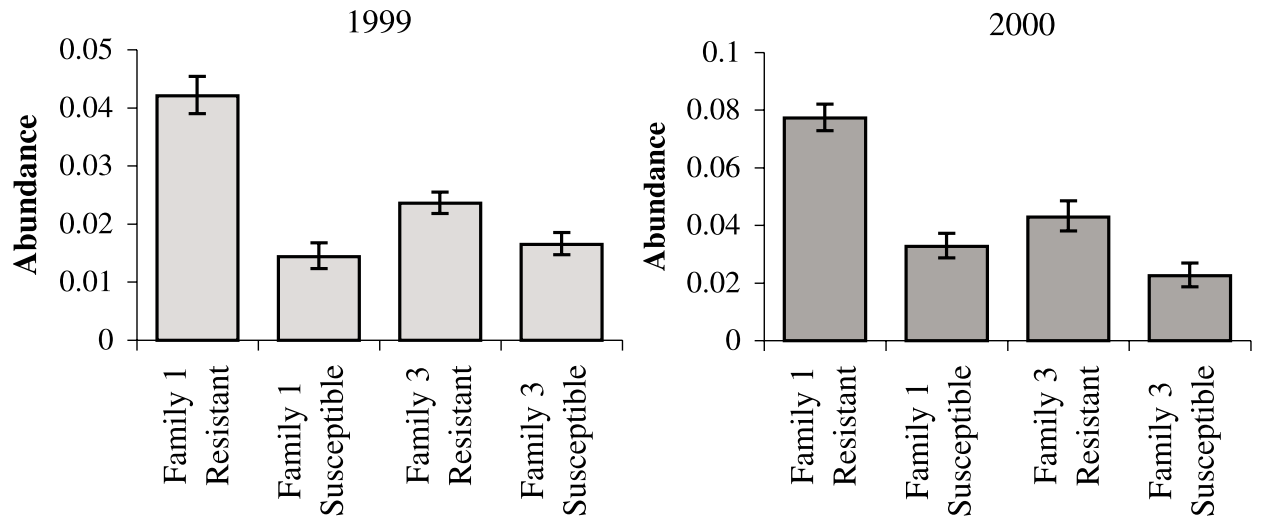

may occur at a much finer scale. The finest level of genetic variation identified in this study was between siblings of an intraprovenance $\mathrm{F}_{2}$, clearly indicating that genetic variation in resistance may occur within a single provenance. Genetic variation in resistance to other insect pests has been shown between families within provenances of Eucalyptus regnans F. Muell., E. nitens (Raymond 1994), and E. globulus (Jordan et al. 2002) again suggesting that resistance can be found at many levels. However, there have been few genetically sound attempts to identify the mechanisms behind this variation within Eucalyptus. Differences noted between susceptible and resistant provenances do not necessarily reflect a causal relationship with resistance, as high interprovenance variability can occur across a large number of traits (e.g., Dutkowski and Potts 1999). The best way to solve this problem and break the genetic disequilibrium in this circumstance is to use segregating progenies (James and Newcombe 2000) where the likelihood of any significant associations between foliar characteristics and resistance being causal is increased. This is due to the fact that recombination during meiosis will tend to randomize the genetic background within, for example, the $\mathrm{F}_{2}$ generation. The identification of genetic variation in resistance to AGM within two $\mathrm{F}_{2}$ families allowed us to undertake a search for possible associations of this variable damage with cuticular waxes.

Aliphatic $\beta$-diketones were the dominant class of cuticular wax compounds identified in the E. globulus juvenile foliage examined, which is consistent with $\mathrm{Li}$ et al. (1997; 65\% of the total wax content) and Wirthensohn et al. (2000; $83 \%$ of the total wax content). Of the eight classes of wax compounds identified between $\mathrm{Li}$ et al. (1997) and Wirthensohn et al. (2000) in Eucalyptus, compounds from five of these were quantified in the present study. We did not quantify any fatty acids, primary alcohols or triterpenoids. The aliphatic $\beta$-diketone $n$-tetratriacontane-16,18-dione, the aldehyde hexadecanal $\left(\mathrm{C}_{16}\right)$, and the ketone heptadecan-2-one have not been reported previously in juvenile E. globulus cuticular wax. While Wirthensohn et al. (2000) reported the presence of aliphatic aromatic esters in Eucalyptus, they do not specifically report the presence of the benzyl and phenylethyl alkanoates of the chain lengths identified in this study. Likewise, Li et al. (1997) did not report the presence of these aliphatic aromatic alkanoates. However, in previous work, Li (1993) did note the presence of this group of com- pounds with similar chain length in E. globulus and suggested that they can account for up to $20-30 \%$ of the total wax content of newly expanded adult leaves of E. globulus, Eucalyptus delegatensis R.T. Bak., and E. regnans but that their levels drop as leaves age. This suggests the possibility that these esters may play a role in the defense of newly developing foliage prior to leaf toughening. Similarly, the levels of wax esters have also been reported to decrease during leaf development in Fagus sylvatica L. (Prasad and Gülz 1990) and Rubus idaeus L. (Shepherd et al. 1999). In the latter case, aging was associated with a concomitant increase in the chain length of the esters. Aliphatic esters are commonly reported in the waxes of other genera (Barthlott et al. 1998; Prasad and Gülz 1990; Shepherd et al. 1999), and a number of our key compounds (e.g., benzyl $n$-tetracosanoate; compound 9) have been reported in the epicuticular waxes of jojoba (Simmondsia chinensis) leaves (Gülz and Marner 1986).

The major discovery of this study is the identification of a group of cuticular wax esters that appear to play a causal role in resistance to AGM. These aliphatic benzyl and phenylethyl alkanoates of carbon chain length ranging from 23 to 26 were consistently present in significantly higher quantities in the resistant classes of both families and in both years, and were also found in higher levels in the more resistant family. Further, these differences are unlikely to be induced by insect feeding (e.g., Karban and Baldwin 1997), because firstly, levels of these compounds did not differ significantly between damaged and undamaged foliage from the same plant and, secondly, no variation in the levels of these compounds was found between undamaged and damaged ramets of the same genotype. Most of the aliphatic wax esters analysed in this study had very high heritabilities, indicating that they are under strong genetic control. Likewise, levels of cuticular wax compounds are under genetic control in other species (Shepherd et al. 1999; Belding et al. 1998). Total wax yield has also been shown to vary between several eucalypt species ( $\mathrm{Li}$ et al. 1997); however, the total wax yield estimated in this study was not significantly heritable and not implicated with insect resistance in this case. The wax compounds that are implicated with insect resistance in this study are minor components of the wax cuticle and do not significantly affect the total wax yield. While in Eucalyptus, a number of studies have shown a significant correlation between increased 1,8-cineole levels and de- 
Fig. 2. Abundance of individual cuticular wax benzyl and phenylethyl alkanoates that vary significantly between resistant and susceptible groups. Means from both families are provided. Data from 1999 (graphs on the left of a pair) and 2000 (graphs on the right of a pair) is provided where available. Quantities (abundance) are expressed as diagnostic ion concentration (GC-MS) of each compound relative to internal standard total ion concentration.

Phenylethyl n-tricosanoate (13)

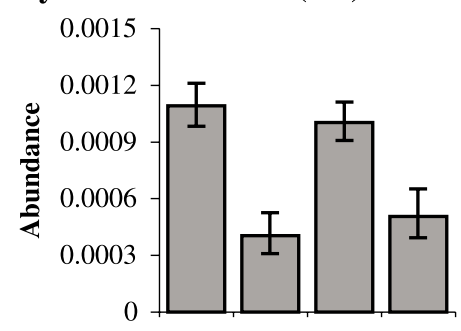

Phenylethyl n-tetracosanoate (14)

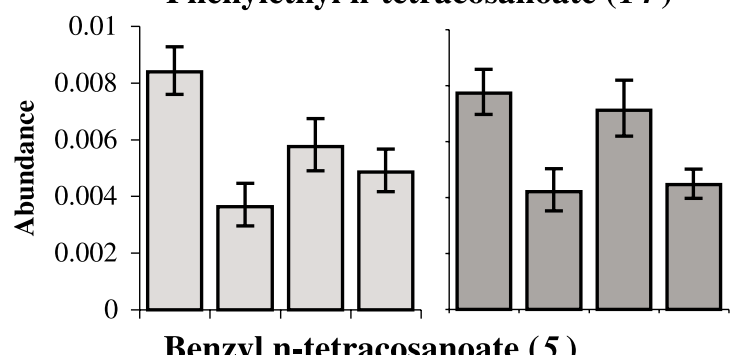

Benzyl n-tetracosanoate (5)

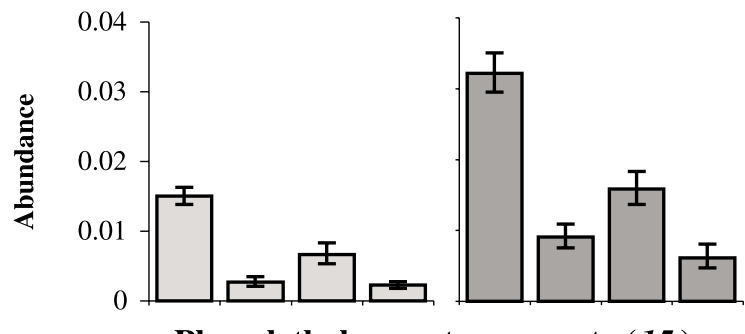

Phenylethyl n-pentacosanoate (15)

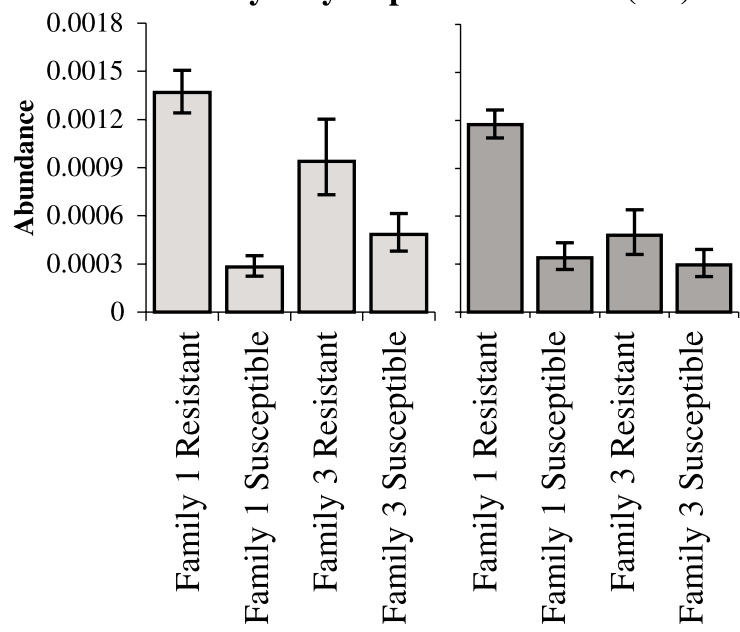

creased susceptibility to insect damage (Stone and Bacon 1994; Li 1993; Edwards et al. 1990, 1993) we found no such associations in this study. In addition to cuticular wax compounds, the relative quantities of the six major volatile oils (1,8-cineole, $\alpha$-pinene, limonene, $\alpha$-terpineol, globulol, and aromadendrene) previously reported for E. globulus juvenile foliage (Boland et al. 1991; Li et al. 1996) and an additional 11 minor terpenoid compounds were also screened in this study, alongside the wax compounds, with no significant correlation between oil compound and resistance being identified (Jones 1999).

\section{Benzyl n-pentacosanoate (6)}
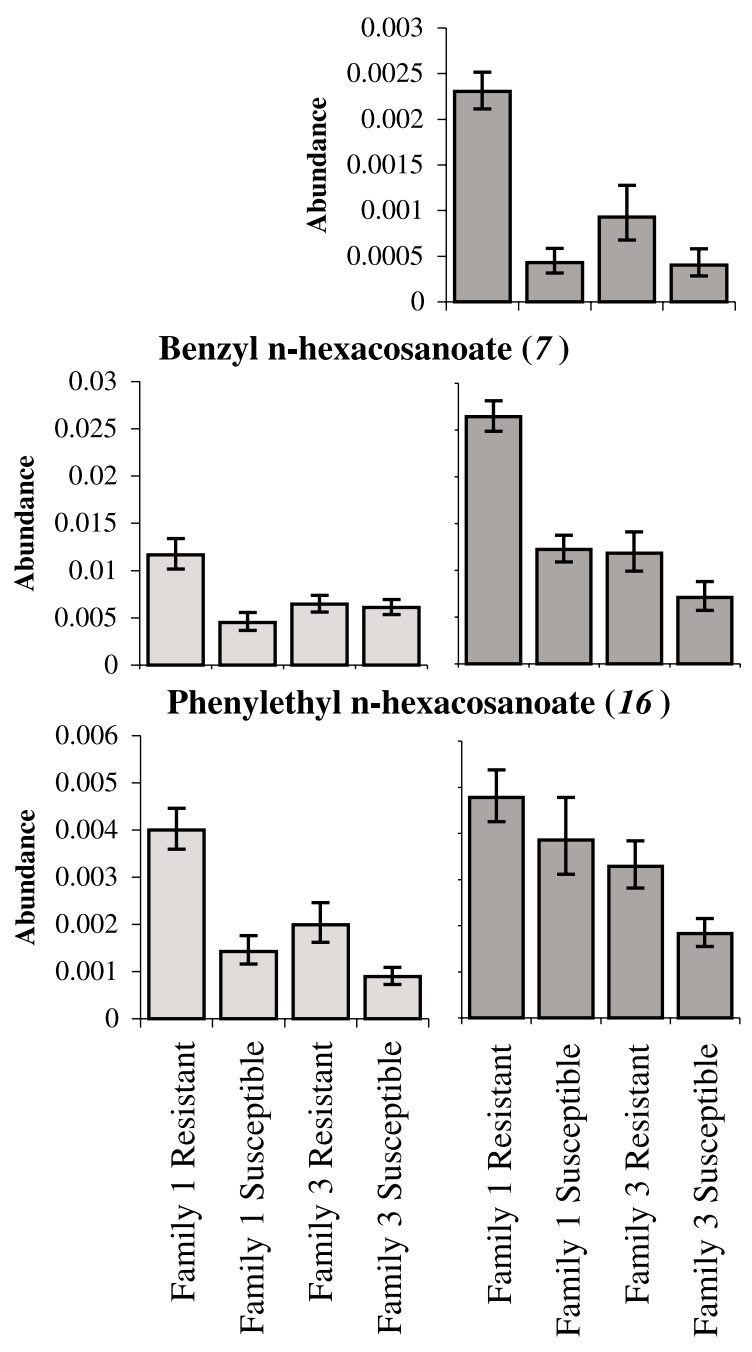

We found no reports implicating the exact phenylethyl and benzyl alkanoates identified by this study in resistance to insects in other plant species. However, insects have been reported to respond to long-chained (Gabel and Thiéry 1996) and simple aromatic esters (Raguso et al. 1996), and benzyl groups can increase the potency of some insecticidal compounds (Nishimura et al. 1994). Subchev et al. (2000) report that 1-methylethyl octanoate acts as a lepidopteran sex pheromone, and Hwang et al. (1977) report larvicidal activity (in mosquito) of aliphatic methyl, ethyl, and isopropyl alkanoates, ranging in carbon chain length from 13 to 21 . 
Fig. 3. Chemical structure of the aliphatic benzyl alkanoates $(a)$ and phenylethyl alkanoates $(b)$ that showed significant variation associated with autumn gum moth damage.

(a) $n=22-24$<smiles>C[14CH2]CC(C)(C)C(=O)OCc1ccccc1</smiles>

Our potentially bioactive benzyl and phenylethyl esters are structurally very similar (Fig. 3), and it is likely that AGM is exhibiting a general response to this group of aliphatic phenylethyl and benzyl esters. It is even possible that AGM responds to a wider range of chain lengths than reported in this study, but our inability to detect a resistance response to esters of other chain lengths may be due to a lack of genetic variation in these compounds within our families. The levels of these phenylethyl and benzyl esters are all positively correlated $(P<0.001$; unpublished data), and it is also possible that the active component is a biosynthetic precursor common to all these compounds. The biosynthetic precursors to these cuticular wax esters, such as long fatty acids (Kolattukudy et al. 1976), were not quantified in these samples. Indeed, this is a common problem with many leaf chemicals where the biosynthetic pathway is complex, involving many intermediate compounds and few known enzymes (Schoonhoven et al. 1998).

There are many ways in which wax compounds may affect insects such as AGM. Insect host selection may be influenced from a distance by cues such as chemical volatiles that may act either as attractants or repellents (Metcalf 1987; Schoonhoven et al. 1998). Host selection may also occur at the leaf surface where the decision to feed or oviposit may be affected by factors such as cuticle morphology (Edwards and Wanjura 1990; Edwards 1982) and leaf chemistry (Chapman 1974). High levels of our bioactive esters could influence AGM at these levels and discourage oviposition. The last stage at which the waxes of a host plant can affect an insect is by reducing larval feeding through biochemical toxicity or indigestibility (e.g., Hemming and Lindroth 1995). Toxic or deterrent chemicals may be either the wax compounds themselves or other compounds held within the wax layer (Chapman 1974; Hemming and Lindroth 1995; Shepherd et al. 1999). Regardless of the mechanism, if the association between these wax esters and AGM damage proves robust across a wider range of genetic material, screening for these compounds may be a useful method of selection for increased AGM resistance in E. globulus.

\section{Acknowledgements}

We thank Gunns Ltd. for cloning the plant material and providing the field site; Andrew Millgate for advice and access to data previously scored from the field trial (height and Mycosphaerella sp. scores); Paul Tilyard, James Foster, Jade Roberts, and Esmé Atkinson for assistance in data collection; and Greg Jordan and Mamoru Matsuki for assistance with the manuscript. (b) $n=21-24$

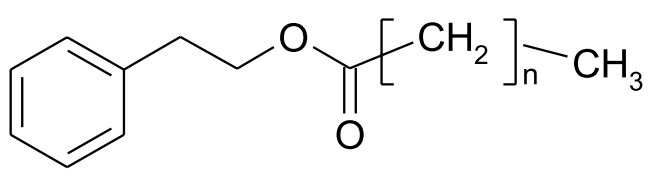

\section{References}

Barthlott, W., Neinhuis, C., Cutler, D., Ditsch, F., Meusel, I., Theisen, I., and Wilhelmi, H. 1998. Classification and terminology of plant epicuticular waxes. Bot. J. Linn. Soc. 126: 237-260.

Belding, R.D., Blankenship, S.M., Young, E., and Leidy, R.B. 1998. Composition and variability of epicuticular waxes in apple cultivars. J. Am. Soc. Hortic. Sci. 123: 348-356.

Birks, J.S., and Kanowski, P.J. 1993. Analysis of resin compositional data. Silvae Genet. 42: 340-350.

Boland, D.J., Brophy, J.J., and House, A.P.N. 1991. Eucalyptus leaf oils. Inkata Press, Melbourne, Sydney, Australia. pp. 79-80.

Chapman, R.F. 1974. The chemical inhibition of feeding by phytophagous insects: a review. Bull. Entomol. Res. 64: 339-363.

Dutkowski, G.W., and Potts, B.M. 1999. Geographical patterns of genetic variation in Eucalyptus globulus ssp. globulus and a revised racial classification. Aust. J. Bot. 46: 237-263.

Edwards, P.B. 1982. Do waxes on juvenile Eucalyptus leaves provide protection from grazing insects? Aust. J. Ecol. 7: 347-352.

Edwards, P.B., and Wanjura, W.J. 1990. Physical attributes of eucalypt leaves and the host range of chrysomelid beetles. Symp. Biol. Hung. 39: 227-236.

Edwards, P.B., Wanjura, W.J., Brown, W.V., and Dearn, J.M. 1990. Mosaic resistance in plants. Nature (London), 347: 434.

Edwards, P.B., Wanjura, W.J., and Brown, W.V. 1993. Selective herbivory by Christmas beetles in response to intraspecific variation in Eucalyptus terpenoids. Oecologia, 95: 551-557.

Elliot, H.J., and Bashford, R. 1978. The life history of Mnesampela privata (Guen.) (Lepidoptera: Geometridae) a defoliator of young eucalypts. J. Aust. Entomol. Soc. 17: 201-204.

Elliot, H.J., and deLittle, D.W. 1984. Insect pests of trees and timber in Tasmania. Forestry Commission, Hobart, Tasmania, Australia.

Falconer, D.S. 1990. Introduction to quantitative genetics. 3rd ed. Longman Scientific \& Technical, John Wiley \& Sons, Inc., New York.

Farrow, R.A., Floyd, R.B., and Neumann, F.G. 1994. Interprovenance variation in resistance of Eucalyptus globulus juvenile foliage to insect feeding. Aust. For. 57: 65-68.

Floyd, R.B., and Farrow, R.A. 1994. The potential role of natural insect resistance in the integrated pest management of eucalypt plantations in Australia. In Forest pest and disease management. Edited by S.C. Halos, F.F. Natividad, L.J. Escote-Carlson, G.L. Enriquez, and I. Umboh. Southeast Asia Regional Centre for Tropical Biology. Bogor, Indonesia. SEAMEO Biotrop. Spec. Publ. 53. pp. 55-76.

Floyd, R.B., Farrow, R.A., and Neumann, F.G. 1994. Inter- and intra-provenance variation in resistance of red gum foliage to insect feeding. Aust. For. 57: 45-48.

Fremlin, R. 1998. Monitoring and surveillance techniques. In Proceedings of the Autumn Gum Moth Workshop Mnesampela privata (Guenee) Monitoring and Control Options. Edited by 
R. Bashford. Cooperative Research Centre for Sustainable Production Forestry, Mildura, Australia. pp. 42-48.

Gabel, B., and Thiéry, D. 1996. Oviposition response of Lobesia botrana females to long-chain free fatty acids and esters from its eggs. J. Chem. Ecol. 22: 161-171.

Gülz, P., and Marner, F. 1986. Esters of benzyl alcohol and 2phenyl-ethanol-1 in epicuticular waxes from Jojoba leaves. Z. Naturforsch. Sect. C, 41: 673-676.

Hemming, D.C., and Lindroth, R.L. 1995. Intraspecific variation in aspen phytochemistry: effects on performance of gypsy moths and forest tent caterpillars. Oecologia, 103: 79-88.

Hwang, Y., Darwazeh, H.A., and Gojrati, H.A.N. 1977. Overcrowding factors of mosquito larvae - larvicidal activity of substituted alkanoic acids and their esters. Proc. Calif. Mosq. Control Assoc. 45: 160-161.

James, R.R., and Newcombe, G. 2000. Defoliation and genetics of insect resistance in cottonwoods. Can. J. For. Res. 30: 85-90.

Jones, T.H. 1999. Genetic variation in susceptibility of Eucalyptus globulus to insects and the role of foliar chemicals in resistance. Unpublished Honours thesis, University of Tasmania, Hobart, Tasmania, Australia.

Jordan, G., Potts, B.M., and Wiltshire, R. 1999. Strong, independent quantitative genetic control of vegetative phase change and first flowering in Eucalyptus globulus ssp. globulus. Heredity, 83: $179-187$.

Jordan, G.J., Potts, B.M., and Clarke, A.R. 2002. Susceptibility of Eucalyptus globulus ssp. globulus to sawfly (Perga affinis ssp. insularis) attack and its potential impact on plantation productivity. For. Ecol. Manage. 160: 189-199.

Karban, R., and Baldwin, I.T. 1997 Induced responses to herbivory. The University of Chicago Press, Chicago, Ill. pp. 1-11.

Kolattukudy, P.E., Croteau, R., and Buckner, J.S. 1976. Biochemistry of plant waxes. In Chemistry and biochemistry of natural waxes. Edited by P.E. Kolattukudy. Elsevier Scientific Publishing Co., Amstersdam. pp. 290-334.

Landsberg, J. 1990. Dieback of rural eucalypts: response of foliar dietary quality and herbivory to defoliation. Aust. J. Ecol. 15: 89-96.

Li, H. 1993. Phytochemistry of Eucalyptus spp., and its role in insect-host-tree selection. Unpublished Ph.D. thesis, University of Tasmania, Hobart, Tasmania, Australia.

Li, H., Madden, J.L., and Potts, B.M. 1996. Variation in volatile leaf oils of the Tasmanian Eucalyptus species. II. Subgenus Symphyomyrtus. Biochem. Syst. Ecol. 24: 547-569.

Li, H., Madden, J.L., and Potts, B.M. 1997. Variation in leaf waxes of the Tasmanian Eucalyptus species. 1. Subgenus Symphyomyrtus. Biochem. Syst. Ecol. 25: 631-657.

Lukacs, Z. 1998. Biology and phenology of M. privata. In Proceedings of the Autumn Gum Moth Workshop Mnesampela privata (Guenee) Monitoring and Control Options. Edited by R. Basford. Cooperative Research Centre for Sustainable Production Forestry, Mildura, Australia. pp. xi-xv.

McQuillan, P.B. 1985. A taxonomic revision of the Australian autumn gum moth genus Mnesampela Guest (Lepidoptera: Geometridae, Ennominae). Entomol. Scand. 16: 175-202.

Metcalf, R.L. 1987. Plant volatiles as insect attractants. Crit. Rev. Plant Sci. 5: 251-301.

Neumann, F.G., and Collett, N.G. 1997. Insecticide trials for control of the steelblue sawfly (Perga affinis affinis), a primary defoliator in young commercial eucalypt plantations in southeastern Australia. Aust. For. 60: 75-83.
Nishimura, K., Kato, S., Holan, G., Ueno, T., and Fujita, T. 1994. Quantitative structure-activity studies of pyrethroids. Pestic. Biochem. Physiol. 50: 60-71.

Ohmart, C.P., and Edwards, P.B. 1991. Insect herbivory on Eucalyptus. Annu. Rev. Entomol. 36: 637-657.

Prasad, R.B.N., and Gülz P. 1990. Developmental and seasonal variations in the epicuticular waxes of beech leaves (Fagus sylvatica L.). Z. Naturforsch. Sect. C, 45: 805-812.

Raguso, R.A., Light, D.M., and Pickersky, E. 1996. Electroantennogram responses of Hyles lineata (Sphingidae, Lepidoptera) to volatile compounds from Clarkia breweri (Onagraceae) and other moth-pollinated flowers. J. Chem. Ecol. 22: 1735-1766.

Raymond, C.A. 1994. Genetic variation in Eucalyptus regnans and $E$. nitens for levels of observed defoliation caused by the eucalypt leaf beetle (Chrysophtharta bimaculata Olivier) in Tasmania. For. Ecol. Manage. 72: 21-29.

Schoonhoven, L.M., Jermy, T., and van Loon, J.J.A. 1998. Insectplant biology from physiology to evolution. Cambridge University Press, Cambridge, U.K.

Shepherd, T., Robertson, G.W., Griffiths, D.W., and Birch, A.N.E. 1999. Epicuticular wax ester and triacylglycerol composition in relation to aphid infestation and resistance in red raspberry (Rubus idaeus L.). Phytochemistry, 52: 1255-1267.

Snedecor, G.W., and Cochrane, W.G. 1980. Statistical methods 7th ed. Iowa State University Press, Ames, Iowa.

Sokal, R.R., and Rohlf, F.L. 1981. Biometry. W.H. Freeman, San Fransisco, Calif.

Stone, C., and Bacon, P.E. 1994. Relationships among moisture stress, insect herbivory, foliar cineole content and the growth of river red gum Eucalyptus camaldulensis. J. Appl. Ecol. 31: 604-612.

Stotz, H.U., Kroymann, J., and Mitchell-Olds, T. 1999. Plant insect interactions. Curr. Opin. Plant Biol. 2: 268-272.

Strauss, S.H., Lande, R., and Namkoong, G. 1992. Limitations of molecular-marker-aided selection in forest tree breeding. Can. J. For. Res. 22: 1050-1061.

Subchev, M., Toshova, T., Stanimirova, L., Stan, G., Embacher, G., Francke, W., Reckziegal, A., Ferreira, J.T., and Priesner, E. 2000. 1-Methylethyl octanaote, a new lepidopteran sex pheromone from the bagworm, Megalophanes viciella. J. Chem. Ecol. 26: $233-236$.

Tibbits, W.N., Boomsma, D.B., and Jarvis, S. 1997. Distribution, biology, genetics, and improvement programs for Eucalyptus globulus and E. nitens around the world. In Proceedings of the 24th Biennial Southern Tree Improvement Conference, 9-12 June 1997. Edited by T. White, D. Huber, and G. Powell. Southern Tree Improvement Committee, Orlando, Fla. pp. 1-15.

Watanabe, J.A., and Watanabe, K.N. 2000. Pest resistance traits controlled by quantitative loci and molecular breeding strategies in tuber-bearing Solanum. Plant Biotechnol. 17: 1-16.

Wills, A., and Burbridge, T. 1995. The autumn gum moth Mnesempala privata: a summary of observations from Western Australia and a possible method of risk assessment. In Proceedings of the Autumn Gum Moth Workshop Mnesampela privata (Guenee) Monitoring and Control Options. Edited by R. Basford. Cooperative Research Centre for Sustainable Production Forestry, Mildura, Australia.

Wirthensohn, M.G., Sedgely, M., and Jones, G.P. 2000. Epicuticular wax of juvenile Eucalyptus leaves and headspace analysis of leaf volatiles. J. Essent. Oil Res. 12: 401-411.

Wu, R., Hu, X., and Han, Y. 2000. Molecular genetics and developmental physiology: implications for designing better forest crops. Crit. Rev. Plant Sci. 19: 377-393. 